https://doi.org/10.15407/ujpe63.3.263

DALAL K. THBAYH, ${ }^{1}$ KAREEMA M. ZIADAN ${ }^{2}$

${ }^{1}$ University of Basra, Polymer Research Centre, Department of Material Science

(Basra, Iraq; e-mail: dalalkarad2014@gmail.com)

${ }^{2}$ University of Basra, College Science, Department of Physics

(Basra, Iraq)

\title{
OPTICAL PROPERTIES OF CONDUCTING POLYMER POLY(O-TOLUIDINE)-DBSA BLENDED WITH POLYETHYLENE OXIDE
}

\begin{abstract}
Conducting polymer poly(O-toluidine) (POT) doped with dodecyl benzene sulfonic acid was prepared by the chemical polymerization with the help of ammonium persulphate $\left(\mathrm{NH}_{4}\right)_{2} \mathrm{~S}_{2} \mathrm{O}_{8}$ as an oxidizing agent. This polymer was blended with different weight ratios (0\%, 10\%, 15\%, 25\%, 35\%, 45\%, 50\%) of poly(ethylene oxide) (PEO) to produce nano conducting polyblend POT-DPSA/PEO, prepared by the spin coating method, and deposited on a glass substrate. The surface morphology was studied by scanning electron microscope. The optical properties of a prepared film was studied from the absorbance spectra at wavelengths 300-1100 nm. The analysis of optical measurement data shows the direct transition with the energy gap decreasing from $2.80 \mathrm{eV}$ to $2.25 \mathrm{eV}$, as the content of PEO increases from $0 \%$ to $50 \%$.

Keywords: conducting polyblend, poly(O-toluidine), polyethylene oxide, optical properties.
\end{abstract}

\section{Introduction}

Intrinsically conductive polymers (ICPs) have become an efficient alternative to inorganic conductors in many practical applications in the recent decade. Polyaniline has been an important member in the ICP family, owing to its easy preparation, excellent environmental stability, various forms, interchangeable oxidation states, electrical and optical properties, and low cost [1-3]. It has various potential applications in many high-performance devices such as rechargeable batteries [4], chemical sensors [5], electrochemical and corrosion devices $[6,7]$ organic light emitting diodes (OLEDs) [8], field-effect transistors (OFETs) [9], and solar cells [10-12]. The common synthesizing method of conducting polymers is, namely, the chemical oxidative [13] or electrochemical [14] polymerization. Various chemical oxidizing agents such as potassium dichromate, potassium io-

(C) DALAL K. THBAYH, KAREEMA M. ZIADAN, 2018 ISSN 2071-0194. Ukr. J. Phys. 2018. Vol. 63, No. 3 date, hydrogen peroxide, and ferric chloride or ammonium persulphate are used. Several studies have been done in order to improve the solubility of polyaniline. Among them, we mention those using functionalized protonic acids as doping, like p-toluenesulphonic acid, dodecyl benzene-sulphonic acid [15], and polystyrene-sulphonic acid [16].

POT polymer is a PANI derivative, which contains the $-\mathrm{CH}_{3}$ group in the orthoposition of the aniline monomer. Among the ring substituted PANI derivatives [17], POT has been probably the most widely studied one. Indeed, the chemical polymerization of (O-toluidine) and its application in solar cells have been studied in [18]. The electropolymerization method of (O-toluidine) was studied by other authors using various electrolytes in various concentrations. These works revealed that POTs have interesting electro-optical properties and can be used as electrochromic and electronic devices [19], while the polymerization of POT doped with DBSA 
by the chemical method has not been reported till now.

Many researches of polymer blends (of two or three polymers) were done to improve the physical properties of polymers $[9,20]$. One of those polymers is PEO, which is used to obtain nanofiberous conducting polymers [21] and is useful for many applications [22]. In the present work, the synthesis of conducting polymer POT-DBSA was executed by the chemical polymerization, and the effects of different wt\% PEO on the optical and morphology properties were studied.

\section{Experimental}

\subsection{Materials}

The (O-tolidine) monomer was provided by Fisher scientific company. Hydrochloric acid $(\mathrm{HCl})$ was provided by Fluka company. Dodecyl benzene sulfonic acid (DBSA) and ammonium persulfate (NH4) ${ }_{2} \mathrm{~S}_{2} \mathrm{O}_{8}$ was provided by Aldrich company. Poly(ethylene oxide) (PEO) was provided by Alpha chemical company. Different solvents were used to process the solution such as chloroform, acetone, ethanol, and methanol were purchased from Sigma Aldrich company.

\subsection{Preparation of poly(O-toluidine) doped with dodecyl benzene sulfonic acid (POT-DBSA)}

Poly (O-toluidine) (POT) doped with DBSA was synthesized by the oxidative polymerization of monomers (O-toluidine) in acidic media with the help of ammonium persulphate $(\mathrm{NH} 4)_{2} \mathrm{~S}_{2} \mathrm{O}_{8}$, as an oxidizing agent. We used a three-neck flask armed with a thermometer and a stirrer. $2.4 \mathrm{gm}$ of O-toluidine monomers where dissolved with $4 \mathrm{ml} \mathrm{HCl}$. The solution was stirred for $1 \mathrm{~h}$. Then a weighted $(5.4 \mathrm{gm})$ DBSA was dissolved with $(20.2 \mathrm{ml}) \mathrm{HCl}$ and left on the stirring for $30 \mathrm{~min}$. A weighted $(4.3 \mathrm{gm})$ of ammonium persulphate $(\mathrm{NH} 4)_{2} \mathrm{~S}_{2} \mathrm{O}_{8}$, as an oxidizing agent, was dissolved with $(24 \mathrm{ml}) \mathrm{HCl}$ and added slowly and carefully to the flask at the temperature of $0{ }^{\circ} \mathrm{C}$. After that, the mixture was kept under a continuous stirring for $24 \mathrm{~h}$. The produced greenish-black precipitate was filtered, by using a vacuum pump, washed with distilled water and methanol, and dried in a vacuum oven at $80^{\circ} \mathrm{C}$ for $12 \mathrm{~h}$. The resultant was a green powder (POT-DBSA).

\subsection{Preparation of the polymer blend (POT-DBSA/PEO)}

This polymer POT-DBSA blend (1mg) was dissolved in $10 \mathrm{ml}$ of chloroform $\left(\mathrm{CHCl}_{3}\right)$ with the stirring for 8-9 h. Poly(ethylene oxide) PEO ( $\mathrm{Mw} 200.000)$ with different weight ratios $(0,10,15,25,35,45$, and 50$) \%$ was added to a POT-DBSA solution under the stirring for $3 \mathrm{~h}$ to produce a nano conducting polyblend (POT-DPSA/PEO). These prepared blends were used to get thin-film samples.

\subsection{Preparation of POT-DBSA/PEO films}

The thin films of POT-DBSA/PEO were synthesized, by using the spin coating method (4000 Electronic Microsystems Model). In this method, the polymer is dissolved in chloroform, the solution was then spread on a rotating substrate. When the solvent is evaporated, the thin polymer layer is remained. The thickness of a film depends on the solution viscosity, rotation rate, and spin speed. The glass substrates used to prepare thin films were cleaned in acetone and distilled water for $10 \mathrm{~min}$, by using a device Ultrasonic Bath. After that, the prepared mixture was deposited on a glass substrate at a speed of $1000 \mathrm{rpm}$ for $20 \mathrm{~s}$. Then the samples were annealed on a hot plate at $60{ }^{\circ} \mathrm{C}$ for $10 \mathrm{~min}$. The thickness of thin films $(60-100 \mathrm{~nm})$ were measured by an ellipsometry spectroscopic unit. The thin films were finally ready for studying the optical properties, by using UV-visible spectra (a Spectro SC from Labomed Inc., USA) at wavelengths of 300-1100 nm. The structure morphology was determined by a scanning electron microscope.

\section{Results and Discussion}

\subsection{Morphology of materials}

The scanning electron microscopy (SEM) can be used to generate the high-resolution images of samples and to show the spatial variations in a chemical composition. In the present investigation, the SEM technique was used to study the surface morphology, compatibility between the polymer blends, and influence of the amount of PEO in a blend. The thin film was prepared by the deposition of the polyblend on a glass substrate. Then the samples were coated with a layer of gold onto the polymer to be ready for measurements. The SEM graphs of thin POT-DBSA films

ISSN 2071-0194. Ukr. J. Phys. 2018. Vol. 63, No. 3 

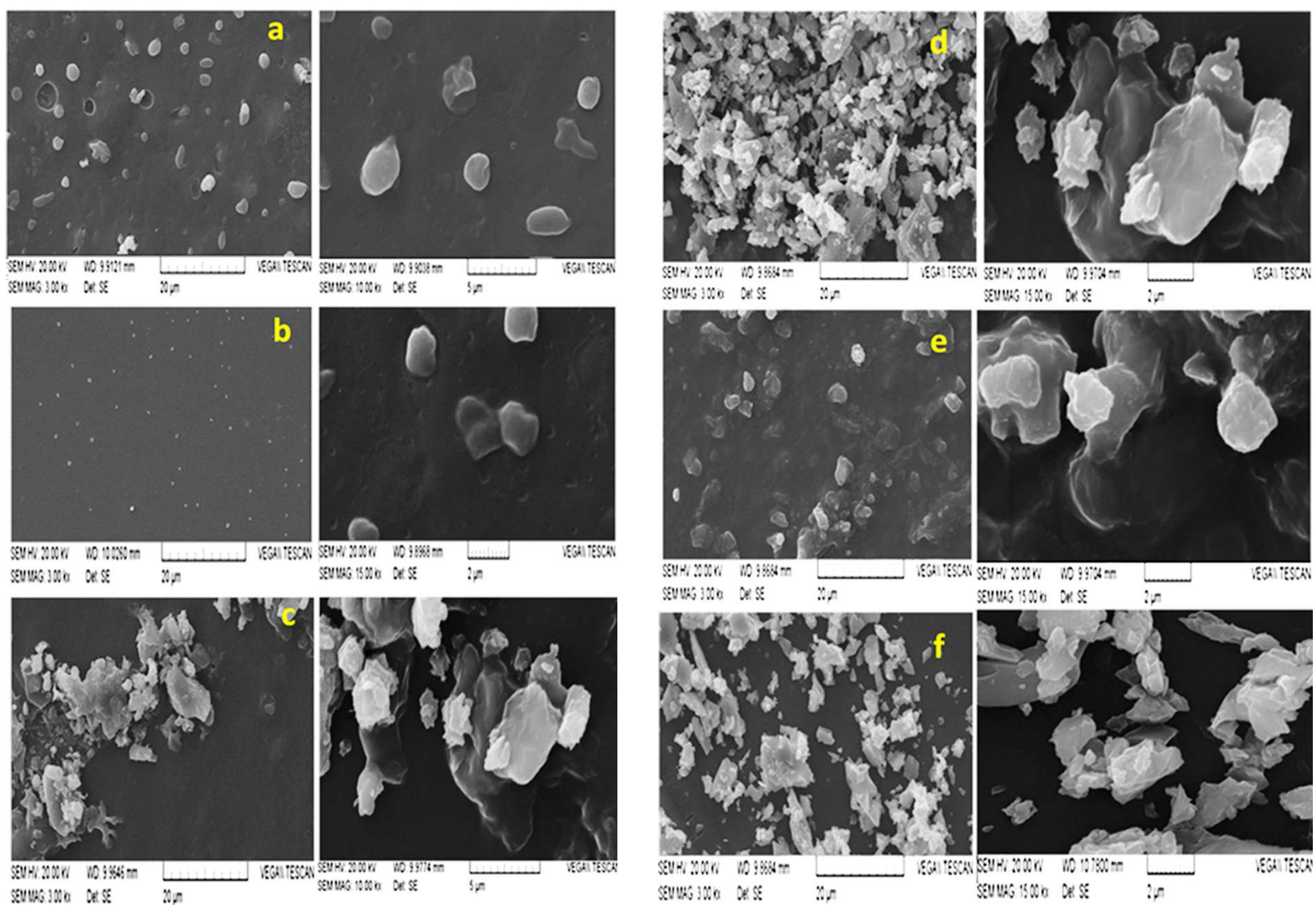

Fig. 1. SEM images of (POT-DBSA/PEO) thin films for all concentrations

with different weight ratios $(0 \%, 10 \%, 15 \%, 25 \%$, $35 \%, 45 \%, 50 \%)$ of PEO are shown in Fig. 1. The shapes show that the mixing process was successful and the blend is homogeneous. We note that the increase in the ratio of $\mathrm{PEO}$ in the mixture reslts in shorter and more tangled chains. The films were uniform, and the examination of their surface morphology did not reveal any presence of pin-holes and porosity [23].

\subsection{Optical characterization}

The optical characterization of thin films gives information about other physical properties, e.g., the energy band gap and band structure, optically active defects, etc. and, therefore, may be of permanent interest for several different applications. Generally, the optical band gap $\left(E_{g}\right)$ and the absorption coefficient $(\alpha)$ can be evaluated from absorbance spectra.

ISSN 2071-0194. Ukr. J. Phys. 2018. Vol. 63, No. 3

\subsubsection{Electronic transition}

The optical data were analyzed with the use of the classical relation for the near edge optical absorption in semiconductors

$\alpha=\alpha_{0} \frac{\left[h v-E_{g}\right]^{r}}{h v}$,

where $\alpha_{0}$ is a constant, and $E_{g}$ is defined as the optical energy band gap between the valence band (VB) and the conduction band $(\mathrm{CB}), v$ is the incident frequency, $h$ is Planck constant, and $r$ is the $(1 / 2,3 / 2$, 2 , and 3 ) for the direct allowed, direct forbidden, indirect allowed, and indirect forbidden transitions, respectively. The type of a transition depends on the absorption coefficient. When $\alpha$ value is larger than $10^{4} \mathrm{~cm}^{-1}$, the transition is called the direct transition, where an electron moves from VB to $\mathrm{CB}$ with the different wave vector $k$, the energy and momentum being conserved. The indirect transition occurs, 


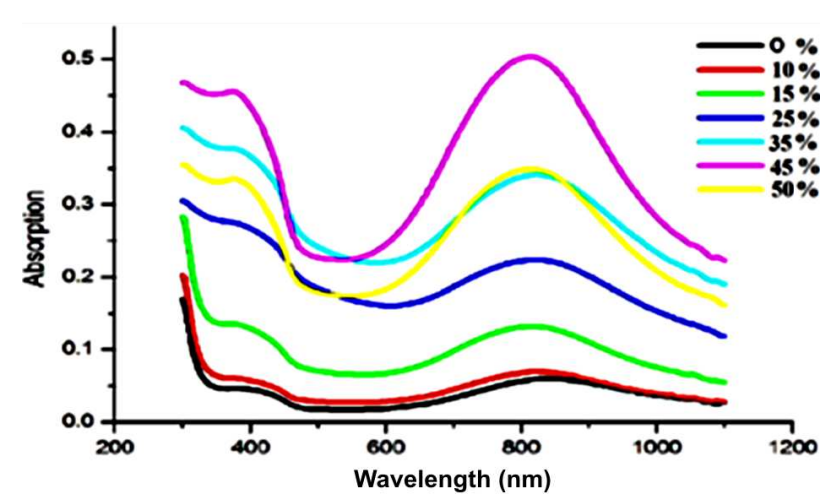

Fig. 2. Absorbance spectra of (POT-DBSA/PEO) thin films as functions of the wavelength for all concentrations

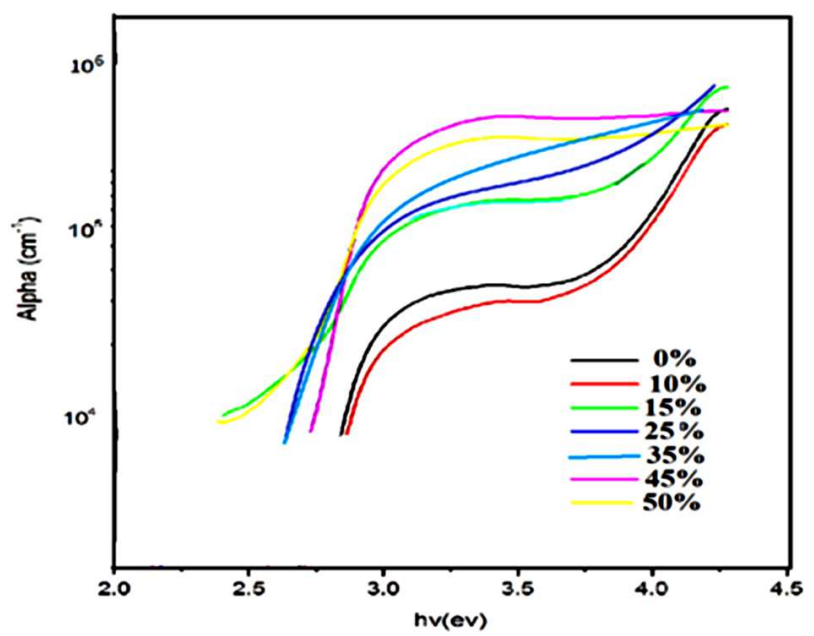

Fig. 3. Relationship between the absorption coefficient and the photon energy for a (POT-DBSA/PEO) thin film for all concentrations

The energy gap in the POT-DBSA/PEO

blend for all concentrations of PEO

\begin{tabular}{|c|c|}
\hline Wt\% PEO & $\begin{array}{c}\text { Energy gap } \\
E_{g}, \mathrm{eV}\end{array}$ \\
\hline 0 & 2.8 \\
15 & 2.65 \\
25 & 2.55 \\
35 & 2.5 \\
45 & 2.4 \\
50 & 2.25 \\
\hline
\end{tabular}

when the value of the absorption coefficient is less than $10^{4} \mathrm{~cm}^{-1}$ and the electrons are transferred from $\mathrm{VB}$ to $\mathrm{CB}$ at the same wave vector $k$. The momentum and energy must be conserved with an assistant
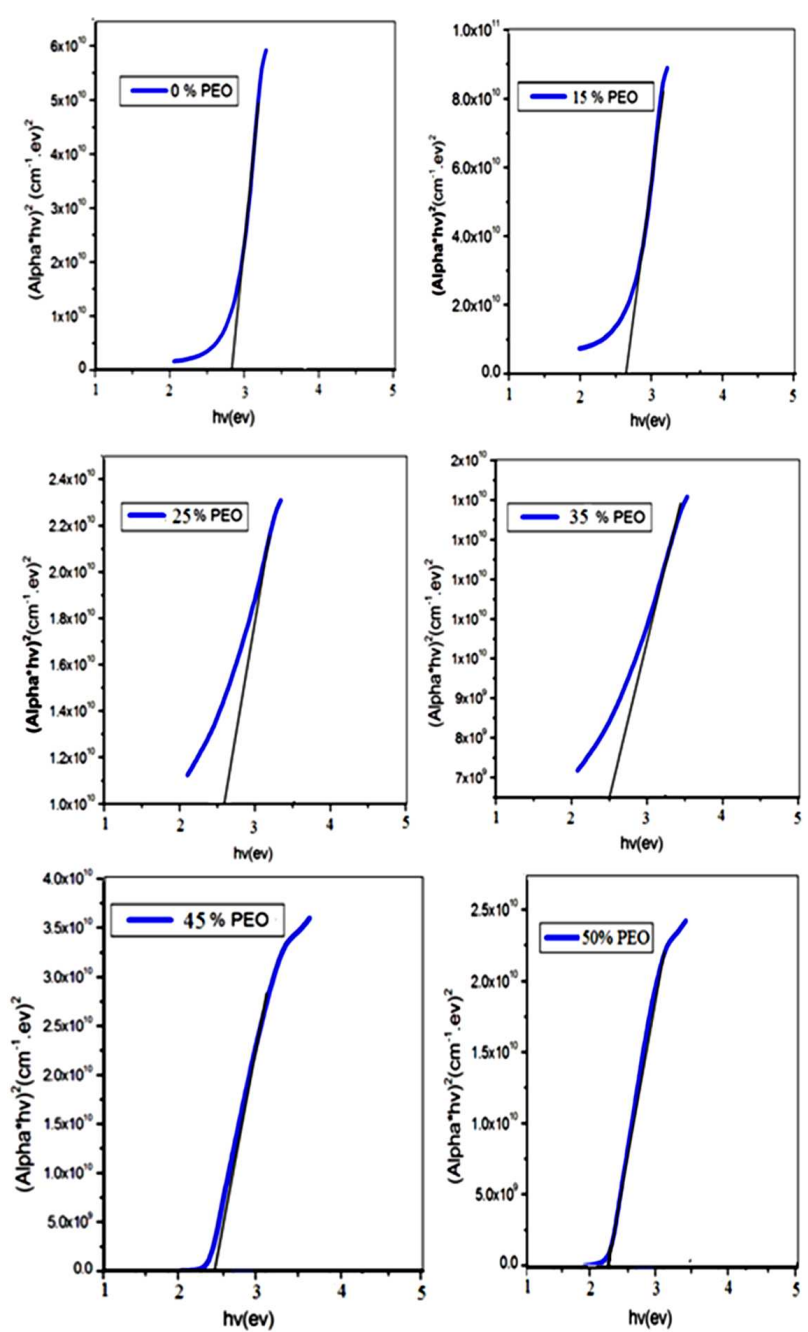

Fig. 4. $(\alpha h v)^{2}$ versus the photon energy for (POT-DBSA/ $\mathrm{PEO})$ thin films for all concentrations

phonon [24]. The absorption coefficient $\alpha$ in the fundamental absorbance region was calculated from the absorption $A$ for a thin film with thickness $t$. In view of relation 2, we have [25]

$\alpha=\frac{2.303}{t} A$

The absorbance spectrum as a function of the wavelength for polyblend POT-DBSA/PEO samples is shown in Fig. 2. The figure presents two peaks at 400 and $800 \mathrm{~nm}$ indicating the presence of bipolaronic bands formed due to the doping with dodecyl benzene sulfonic acid (DBSA) [26]. The result indicates that the location of the absorption band goes

ISSN 2071-0194. Ukr. J. Phys. 2018. Vol. 63, No. 3 
toward the short wavelengths, as the fraction of $\mathrm{PEO}$ in the polyblend (POT-DBSA/PEO) increases. Figure 3 shows the relationship between the absorption coefficient of a thin film and the photon energy for different contents of PEO in the polyblend (POT$\mathrm{DBSA} / \mathrm{PEO})$. The value of the absorption coefficient plays an important role in the limitation of the type of a transition. From Fig. 3, the value of $\alpha$ greater than $10^{4} \mathrm{~cm}^{-1}$ indicates that we deal with a direct electron transition. The optical band gap is determined from the plot $(\alpha h v)^{2}$ as a function of the photon energy, by using Eq. (1), and is shown in Fig. 4. The energy gap is obtained, by extrapolating the linear region of the plot $(\alpha h v)^{2}=0$. The band energy gap $E_{g}$ decreases from $2.8 \mathrm{eV}$ to $2.25 \mathrm{eV}$, when the PEO content increases from $0 \%$ to $50 \%$, as indicated in Table.

\section{Conclusion}

The conducting polyblend of POT-DBSA/PEO was prepared for different weight ratios of $\mathrm{PEO}$. The analysis of the optical measurement data showed the direct transition, where the energy gap decrease from $2.8 \mathrm{eV}$ to $2.25 \mathrm{eV}$, as the $\mathrm{PEO}$ content increases from $0 \%$ to $50 \%$. The surface morphology indicates the structure of DBSA-doped POT.

The authors would like to thank the University of Basra, College of Science, Department of Physics and Polymer Research Centre, and Department of Material Science.

1. P.-C. Wang, et al. Transparent electrodes based on conducting polymers for display applications. Displays 34 (4), 301 (2013).

2. M. Jaymand. Recent progress in chemical modification of polyaniline. Progress in Polymer Science 38 (9), 1287 (2013).

3. X. Guo, M. Baumgarten, K. Müllen. Designing $\pi$-conjugated polymers for organic electronics. Progress in Polymer Science 38 (12), 1832 (2013).

4. Y. Zhao, S. Si, C. Liao. A single flow zinc//polyaniline suspension rechargeable battery. J. Power Sources 241, 449 (2013).

5. L. Wang et al. Graphene sheets, polyaniline and AuNPs based DNA sensor for electrochemical determination of $\mathrm{BCR} / \mathrm{ABL}$ fusion gene with functional hairpin probe. Biosensors and Bioelectronics 51, 201 (2014).

6. G. Gupta et al. Polyaniline-lignosulfonate/epoxy coating for corrosion protection of AA2024-T3. Corrosion Science 67, 256 (2013).
7. A.R. Elkais et al. The influence of thin benzoate-doped polyaniline coatings on corrosion protection of mild steel in different environments. Progress in Organic Coatings 76(4), 670 (2013).

8. P.L. Burn, S.C. Lo, I.D. Samuel. The development of lightemitting dendrimers for displays. Advanced Materials 19 (13), 1675 (2007).

9. S. Nam et al. Solvent-free solution processed passivation layer for improved long-term stability of organic field-effect transistors. J. Mater. Chem. 21 (3), 775 (2011).

10. K. Ziadan, H. Hussein, K. Ajeel. Study of the electrical characteristics of poly (o-toluidine) and application in solar cell. Energy Procedia 18, 157 (2012).

11. E.L. Williams et al. Conducting polymer and hydrogenated amorphous silicon hybrid solar cells. Appl. Phys. Lett. 87 (22), 223504 (2005).

12. P.-J. Alet et al. Hybrid solar cells based on thin-film silicon and P3HT-A first step towards nano-structured devices. Europ. Phys. J. Appl. Phys. 36 (3), 231 (2006).

13. N. Gospodinova, L. Terlemezyan. Conducting polymers prepared by oxidative polymerization: polyaniline. Progress in Polymer Science 23 (8), 1443 (1998).

14. K. Gurunathan et al. Electrochemically synthesised conducting polymeric materials for applications towards technology in electronics, optoelectronics and energy storage devices. Mater. Chem. Phys. 61 (3), 173 (1999).

15. A.J. Heeger. Polyaniline with surfactant counterions: Conducting polymer materials which are processible in the conducting form. Synthetic Metals 57 (1), 3471 (1993).

16. Y. Kang, M.-H. Lee, S.B. Rhee. Electrochemical properties of polyaniline doped with poly (styrenesulfonic acid). Synthetic Metals 52 (3), 319 (1992).

17. A. Elmansouri et al. Spectroscopic characterization of electrodeposited poly(o-toluidine) thin films and electrical properties of ITO/poly(o-toluidine)/aluminum schottky diodes. Active and Passive Electronic Components 2007, 7 (2007).

18. M.Z. Kareema, F. Hussein. K.I. Ajeel. Study of the electrical characteristics of poly(o-toluidine) doped with paratoluene sulphonic acid/ $n$-type silicon heterojunction solar cells. In: 2nd international conference on solar energy materials (solar Asia 2013) 22-24 Ague, Universiti Malaya, 50603, Kuala Lumpur. Malaysia 250 (2013).

19. M. Kareema, W.T.S. Ziadan. Study of the electrical characteristics of polyaniline prepared electrochemical polymerization (Energy procedia, 2012).

20. W. Pan, Q. Zhang, Y. Chen. Characterization of PAN/ PANI-DBSA blend nanofibers produced by electrospinning method. Optoelectron Adv. Mater Rapid Commun. 4, 2118 (2010).

21. T.J. Alwan, K.M. Ziadan, K.K. Kadhum. Alignment Nanofibers Conducting Polymer (PAni. CSA/PEO) Preparation by Electrospinning Technique. Intern. Review Phys. (IREPHY) $7(2), 185$ (2013). 
22. J.M. Deitzel et al. The effect of processing variables on the morphology of electrospun nanofibers and textiles. Polymer 42 (1), 261 (2001).

23. A. Elmansouri et al. Spectroscopic characterization of electrodeposited poly (o-toluidine) thin films and electrical properties of ITO/poly (o-toluidine)/aluminum Schottky diodes (Active and Passive Electronic Components, 2007).

24. Y. Ramadin et al. Optical properties of epoxy-glass microballoons composite. Optical Materials 5 (1-2), 69 (1996).

25. F. Al-Eithan, M. Al-Edani, A. Abass. Optical Band of Triglycine Selenate (TGSe) Single Crystals. Phys. Status Solidi A 103(2), 571 (1987).

26. M.R. Safenaz, M. Sheikha. Synthesis and electrical properties of polyaniline composite with silver nanoparticles (Advances in Materials Physics and Chemistry, 2012).

Received 22.01.18
Д.К. Тбейх, К.М. Зіадан

ОПТИЧНІ ВЛАСТИВОСТІ ПРОВІДНОГО ПОЛІМЕРУ ПОЛІ(О-ТОЛУЇДИН)-ДБСК, ЗМІШАНОГО З ОКСИДОМ ПОЛІЕТИЛЕНУ

$\mathrm{P}$ е $з$ ю м е

Провідний полімер полі(О-толуїдин) (ПІТ), легований додецил бензол сульфоновою кислотою (ДБСК), було приготовано хімічною полімеризацією за допомогою персульфата амонію $\left(\mathrm{NH}_{4}\right)_{2} \mathrm{~S}_{2} \mathrm{O}_{8}$ як окислювача. Цей полімер змішувався з поліоксидом етилену (ПВЕ) в різних вагових співвідношеннях $(0 \%, 10 \%, 15 \%, 25 \%, 35 \%, 45 \%, 50 \%)$ для отримання методом центрифугування провідної наносуміші ПОТДБСК/ПВЕ, яка наносилася на підкладку зі скла. Морфологію поверхні досліджено методом растрової електронної мікроскопії. Оптичні властивості плівки вивчені за спектрами поглинання на довжинах хвиль 300-1100 нм. Аналіз оптичних даних показує прямий перехід зі зменшенням ширини забороненої зони з 2,80 еВ до 2,25 еВ при збільшенні вмісту ПВЕ від $0 \%$ до $50 \%$ 